\title{
Phylogenetic comparison of the cyanobacterial genera Anabaena and Aphanizomenon
}

\footnotetext{
${ }^{1}$ Department of Applied Chemistry and Microbiology, PO Box 56, Biocenter Viikki, 00014 Helsinki University, Finland

2 Department of Marine Ecology, National Environmental Research Institute, PO Box 358, DK4000 Roskilde, Denmark

3 Laboratoire de Cryptogamie, Muséum National d'Histoire Naturelle, 12 rue Buffon, 75005 Paris, France

${ }^{4}$ INRA, UMR CARRTEL, BP 511, 74203 Thonon-lesBains cedex, France
}

\author{
Muriel Gugger, ${ }^{1} \dagger$ Christina Lyra, ${ }^{1}$ Peter Henriksen, ${ }^{2}$ Alain Couté, ${ }^{3}$ \\ Jean-François Humbert ${ }^{4}$ and Kaarina Sivonen ${ }^{1}$
}

Author for correspondence: Kaarina Sivonen. Tel: +358 9 19159270. Fax: + 358919159322. e-mail: kaarina.sivonen@helsinki.fi

\begin{abstract}
Morphological analysis and sequencing of the 165 rRNA gene, the spacer region of the ribosomal operon (ITS1) and the rbcLX (RubisCO) region was performed on 26 Anabaena strains and 14 Aphanizomenon strains isolated from several lakes in Denmark, Finland and France. Based on their morphology, Anabaena strains differed from strains of Aphanizomenon: the vegetative cells, heterocysts and akinetes were significantly wider in Anabaena than in Aphanizomenon. Phylogenetic trees based on the 16S rDNA, ITS1 and rbcLX regions showed that the planktic Anabaena strains were not distinguishable from Aphanizomenon strains. The results of the clustering of Anabaena and Aphanizomenon strains based on 165 rDNA sequences showed that these two genera are not monophyletic. Sequence analysis of the 16S rDNA, ITS1-S and rbcLX regions of the planktic Anabaena strains showed that this genus is heterogeneous. In all methods, Anabaena strains that produced different toxic compounds (e.g. anatoxin-a, microcystin and an unknown neurotoxin) were clustered separately from each other but were grouped either with non-toxic Anabaena and/or Aphanizomenon strains. Our data suggest that the planktic Anabaena and Aphanizomenon isolates belong to the same genus, regardless of their morphological differences. Thus, a taxonomic revision of the two genera is required.
\end{abstract}

Keywords: Anabaena, Aphanizomenon, 16S rDNA, 16S-23S rDNA, RubisCO spacer

\section{INTRODUCTION}

The genera Anabaena and Aphanizomenon have been classified into the filamentous heterocystous cyanobacteria (subsection IV, family I) (Rippka et al., 2001). Under the Botanical Code, the cyanobacterial genera Anabaena Bory ex Born. et Flah. and Aphanizomenon Morren ex Born. et Flah. belong to the order Nostocales (Komárek \& Anagnostidis, 1989). The genus Anabaena is distinguished from the genus Aphanizomenon based on the botanical type species Anabaena (An.) oscillarioides Bory and Aphanizomenon (Ap.) flos-aquae (L.) Ralfs. Komárek \& Kováčik (1989)

Published online ahead of print on 19 April 2002 as DOI 10.1099/ ijs.0.02270-0.

†Present address: Centre de Recherche Public - Gabriel Lippmann, 162a avenue de la Faïencerie, L-1511 Luxembourg, Grand Duché de Luxembourg.

The GenBank/EMBL accession numbers for the cyanobacterial sequences determined in this study are AJ293102-AJ293131 (16S rDNA), AJ293101, AJ293171-AJ293215 and AJ294540 (ITS1) and AJ293132-AJ293170 (rbcLX). evaluated the morphological features used for the differentiation of Anabaena and Aphanizomenon, such as the structure of the trichomes, the elongated and narrowed terminal cells, the fascicle-like colonies and the development of the heterocysts. Only the structure of the trichomes appeared to be genus-specific. In addition, the occurrence of strains with intermediate characters in field samples indicated the problem of generic delimitation between Anabaena and Aphanizomenon (Komárek \& Anagnostidis, 1989).

Anabaena and Aphanizomenon are able to fix nitrogen and form mass occurrences (water blooms) in fresh water and in the Baltic Sea (Sivonen et al., 1990; Barker et al., 2000). Comparative physiological studies have shown differences between strains of these genera, such as the higher growth affinity for light of Ap. flosaquae PCC 7905 and the enhanced growth of an Anabaena strain under phosphate-limited conditions (De Nobel et al., 1997, 1998). Anabaena species may synthesize neurotoxic alkaloids such as anatoxin-a, anatoxin-a(S) or saxitoxins and Aphanizomenon strains 
synthesize saxitoxins or anatoxin-a (Sivonen \& Jones, 1999). Several Anabaena species also produce a wide variety of heptapeptide hepatotoxins, the microcystins (Sivonen et al., 1992), while Aphanizomenon ovalisporum may synthesize alkaloid cytotoxins, the cylindrospermopsins (Banker et al., 1997, 2000).

Molecular studies have shown that Anabaena and Aphanizomenon strains are closely related. Strains of the two genera contained similar non-polar fatty acids, whole-cell fatty acids and whole-cell proteins (Lyra et al., 1997; Li et al., 1998; Gugger et al., 2002). In addition, RFLP analysis and sequencing of the 16S rRNA gene have revealed a very close relationship between certain strains of Anabaena and Aphanizomenon (Neilan et al., 1995; Rudi et al., 1997; Lyra et al., 1997, 2001; Iteman et al., 1999; Rudi \& Jakobsen, 1999). However, the small number of Aphanizomenon strains investigated so far has hindered taxonomic conclusions at the generic level and has emphasized the need for further studies.

To study the relationship between the genera Anabaena and Aphanizomenon, we examined 26 strains of Anabaena and 14 strains of Aphanizomenon originating mainly from lakes in Denmark, Finland and France. The Anabaena strains belonged to several species based on classical morphological criteria and produced at least three types of toxic compounds, microcystins, anatoxin-a and an unknown neurotoxin. The Aphanizomenon strains were non-toxic and were classified as Ap. flos-aquae and Aphanizomenon gracile. The genotypic characteristics of the strains were investigated based on the 16S rDNA, the internal transcribed spacer between the 16S and 23S rDNA (ITS1) and $\operatorname{rbcLX}$ (RubisCO) with the intergenic spacer regions.

\section{METHODS}

Organisms and growth conditions. The strains used in this study are listed in Table 1. Morphological identification of the strains has been reported in previous studies (Sivonen et al., 1989, 1992) or strains were identified in this study according to Geitler (1932). All strains were clonal isolates cultured in liquid Z8 medium (Kotai, 1972) with or without nitrogen at a constant temperature $\left(20^{\circ} \mathrm{C}\right)$ and continuous light $\left(20 \mu \mathrm{mol}\right.$ quanta $\left.\mathrm{m}^{-2} \mathrm{~s}^{-1}\right)$. Microphotographs of the strains were taken using a Photometrics Sensys digital camera, PV Cam with Olympus (Provis) AX 70. The pictures were then processed with Image Pro Plus.

Toxicity. The toxicity of the strains has been described in previous studies (Sivonen et al., 1989, 1992; Henriksen, 1996; Henriksen et al., 1997; Lyra et al., 2001) or was determined in this study by ELISA (enviroGard Microcystins Plate Kite, Strategic Diagnostics) or HPLC (Helwett Packard HP1090) as described in Lyra et al. (2001).

Morphology. The shapes and dimensions of the vegetative cells, heterocysts and akinetes from Anabaena and Aphanizomenon cultures were recorded during the exponential growth phase by light microscopy. Growth was measured as $\mathrm{OD}_{750}$.

Oligonucleotide primers. Three sets of primers specific for cyanobacterial strains were used to amplify the $16 \mathrm{~S}$ rDNA,
ITS1 and $r b c L X$ (RubisCO) loci. The 16S rDNA was amplified and sequenced using the eubacterial primer $8 \mathrm{~F}$ (Lane, 1991) and primer 1480 (5'-AGTCCTACCTTAGGCATCCCCCTCC-3'), specific for heterocystous cyanobacteria and designed in this study. To retrieve the complete sequence of both strands, the forward primers $400\left(5^{\prime}-\right.$ AAGGCTCTTGGGTTGTAAACC-3') and 861 (5'-TAACGCGTTAAGTATCCC-3') and the reverse primers 521 (5'-ACCTGCGGACCCTTTACGC-3') and 1061 (5'-CTTGGTAAGGTTCTTGCG-3') were used. ITS1 and the $r b c L X$ loci were amplified and sequenced with the primers 16CITS and 23CITS (Neilan et al., 1997b), CX, CW and DN (Rudi et al., 1998) and Rubi (5'-AGGAGGATTTGTTTCGCCTAGC-3'), designed in this study.

PCR amplification. PCR amplification of $16 \mathrm{~S}$ rDNA and ITS1 was performed in a volume of $50 \mu 1$ containing $2 \mu \mathrm{l}$ of clonal culture, $200 \mu \mathrm{M}$ dNTPs, $20 \mu \mathrm{M}$ of each primer and $5 \mu 110 \times$ PCR buffer. The template was boiled for $10 \mathrm{~min}$ prior to the addition of $1 \mathrm{U}$ DynaZyme thermostable DNA polymerase (Finnzymes). The thermal-cycling conditions were 5 min denaturation at $97^{\circ} \mathrm{C}, 30$ cycles of 15 s denaturation at $94{ }^{\circ} \mathrm{C}, 30 \mathrm{~s}$ annealing at $48^{\circ} \mathrm{C}$ and $1 \mathrm{~min}$ extension at $72{ }^{\circ} \mathrm{C}$, followed by final $5 \mathrm{~min}$ elongation at $72^{\circ} \mathrm{C}$. The rbcLX locus was amplified as described by Rudi et al. (1998). The concentration of the amplified products was checked on $1 \%$ agarose gels and the products were purified with the Wizard PCR Preps DNA purification system (Promega).

Separation of the ITS1 PCR products by capillary electrophoresis. To determine the length variation of the ITS1, primers 16CITS and 23CITS (Neilan et al., 1997b) were labelled at the $5^{\prime}$-end with $S 5^{\prime}-6$-carboxyfluorescein and $5^{\prime}-4$, $7,2^{\prime}, 4^{\prime}, 5^{\prime}, 7^{\prime}$-hexachloro-6-carboxyfluorescein, respectively. PCR amplifications were performed as described above except that one-third of the primers were labelled. The PCR products were harvested according to the manufacturer's instructions and separated at $60^{\circ} \mathrm{C}$ for $40 \mathrm{~min}$ with internal size standard GENESCAN 2500 using an ABI PRISM 310 Genetic Analyzer (Perkin Elmer) with Performance Optimized Polymer 4 and the GENESCAN mode.

Sequencing. PCR products of the $16 \mathrm{~S}$ rDNA and $r b c L X$ were sequenced directly. Prior to sequencing, the ITS1 PCR products were either excised from the agarose gel or cloned using the pGEM-T Easy vector system (Promega) when several PCR products of the same size were detected by capillary electrophoresis. DNA sequencing was performed with the ABI PRISM Big Dye Terminator cycle sequencing ready reaction kit (Perkin Elmer) and an ABI PRISM 310 Genetic Analyzer (Perkin Elmer) according to the manufacturer's instructions. The sequenced fragments were assembled into contigs using GeneDoc version 2.6 (Nicholas \& Nicholas, 1997).

Phylogenetic trees. The sequences were aligned using the program PILEUP of the GCG package version 10.1 (Genetics Computer Group, Madison, WI, USA) and corrected manually using GeneDoc version 2.6. Phylogenetic trees were constructed using the neighbour-joining method on Jukes and Cantor distances and the Wagner parsimony method of PHYLIP version 3.5c (Felsenstein, 1993). Bootstrap analysis of 500 resamplings was performed for each consensus tree. Only bootstrap values above $80 \%$ are indicated at the nodes of the trees. The trees were edited using TreeView version 1.6.1 (Page, 1996). The 16S rDNA and rbcLX sequences of Microcystis and Planktothrix and the ITS1-S sequence of Nostoc sp. PCC 7120 were chosen as outgroups for the respective trees. 
Table 1. Cyanobacterial strains used in this study

Culture collections: PH, P. Henriksen (Denmark); PMC, National Museum of Natural History (France); NC, Niva-Cya, Norwegian Institute for Water Research (Norway); NIES, National Institute for Environmental Studies (Japan); PCC, Institut Pasteur (France). Strain IC-1 was provided by W. W. Carmichael (Wright State University, Dayton, OH, USA).

\begin{tabular}{|c|c|c|c|}
\hline Strain & $\begin{array}{c}\text { Geographical origin/year of } \\
\text { isolation* }\end{array}$ & $\begin{array}{l}\text { Toxicity/ } \\
\text { toxin } †\end{array}$ & Reference(s) \\
\hline \multicolumn{4}{|l|}{ Anabaena circinalis } \\
\hline 86 & Lake Villikalanjärvi, FI/1986 & A & $2,8,11,22$ \\
\hline $123 \S$ & Lake Säyhteenjarvi, FI/1986 & A & $2,3,8,12,18,22,23$ \\
\hline $90 \S$ & Lake Vesijärvi, FI/1986 & M & $3,6,8,10,12,15,18,21-23$ \\
\hline \multicolumn{4}{|l|}{ Anabaena compacta } \\
\hline PH118 & Lake Langesø, DK/1993 & NT & \\
\hline PH189 & Lake Tuel, DK/1993 & NT & \\
\hline Anabaena crassa $\mathrm{PH} 215$ & Lake Hjulby (Fyn), DK/1994 & NT & \\
\hline \multicolumn{4}{|l|}{ Anabaena cf. cylindrica } \\
\hline PH133 & Lake Arresø, DK/1993 & $\mathrm{N}$ & \\
\hline PMC9705 & Dam of Champsanglard, FR/1997 & NT & \\
\hline \multicolumn{4}{|l|}{ Anabaena flos-aquae } \\
\hline 14 & Lake Sääskjärvi, FI/1985 & A & $2,7,8,12,18,22$ \\
\hline $37 \S$ & Lake Sääskjärvi, FI/1985 & A & $2,8,12,21,23$ \\
\hline $202 \mathrm{~A} 1 \S$ & Lake Vesijärvi, FI/1987 & M & $3,5,6,8,10,12,15,18,22,23$ \\
\hline \multicolumn{4}{|l|}{ Anabaena lemmermannii } \\
\hline $\mathrm{NC} 83 / 1 \S$ & Lake Edlandsvatnet, NW/1981 & M & $6,8,10,12,15,17-20,22,23$ \\
\hline $66 \mathrm{~A} \S$ & Lake Sääskjärvi, FI/1986 & M & $3,4,6,8,10,12,18,22,23$ \\
\hline $202 \mathrm{~A} 2 \S$ & Lake Vesijärvi, FI/1987 & M & $3,5,6,8,10,12,22,23$ \\
\hline PH 256 & Lake Knud, DK/1994 & M & 13 \\
\hline Anabaena cf. lemmermannii $\mathrm{PH} 262$ & Lake Knud, DK/1994 & NT & 13 \\
\hline Anabaena macrospora PMC9301 & Lake Aydat, FR/1993 & NT & \\
\hline Anabaena mendotae $\mathrm{PH} 57$ & Lake Velje Sø, DK/1993 & NT & \\
\hline Anabaena planctonica $\mathrm{PH} 71$ & Lake Furesø, DK/1993 & NT & \\
\hline Anabaena solitaria 82 & Lake Karpjärvi, FI/1986 & NT & \\
\hline \multicolumn{4}{|l|}{ Anabaena spiroides } \\
\hline PMC9403 & Lake Aydat, FR/1994 & NT & \\
\hline PMC9702 & Dam of Champsanglard, FR/1997 & NT & \\
\hline Anabaena sp. PMC9701 & Dam of Champsanglard, FR/1997 & NT & \\
\hline Anabaena sp. $277 \S$ & River Perniönjoki, FI/1991 & NT & $8,12,18,22,23$ \\
\hline Anabaena sp. 299 & Lake Vesijärvi, FI/1992 & NT & 18 \\
\hline Anabaena sp. IC-1 & Cave Lake, ID, USA/1988 & A & \\
\hline \multicolumn{4}{|l|}{ Aphanizomenon flos-aquae } \\
\hline NIES $81 \S$ & Lake Kasumigama, JP/1978 & NT & $9,14,15,22$ \\
\hline $202 \S$ & Lake Vesijärvi, FI/1987 & NT & $12,18,22,23$ \\
\hline TR183 & Baltic Sea/1993 & NT & $10,12,18,20,22,23$ \\
\hline PMC9401 & Lake Aydat, FR/1994 & NT & \\
\hline PMC9706 & Dam of Champsanglard, FR/1997 & NT & \\
\hline PMC9707 & Dam of Champsanglard, FR/1997 & NT & \\
\hline 326 & Lake Lohjanjärvi, FI/1998 & NT & \\
\hline PCC $7905 \S$ & Lake Brielse Meer, NL/? & NT & $1,9,12,20,22,23$ \\
\hline \multicolumn{4}{|l|}{ Aphanizomenon flos-aquae var. klebahnii } \\
\hline PH83 & Lake Fure sø, DK/1993 & NT & \\
\hline PH218 & Lake Birkerød, DK/1993 & NT & \\
\hline Aphanizomenon cf. flos-aquae PMC9501 & Lake Chambon, FR/1995 & NT & \\
\hline Aphanizomenon cf. gracile $\mathrm{PH} 271 \S$ & Lake Nørre, DK/1994 & NT & 22,23 \\
\hline \multicolumn{4}{|l|}{ Aphanizomenon gracile } \\
\hline PH $219 \S$ & Lake Madesø, DK/1994 & NT & 22,23 \\
\hline PMC9402 & Lake Aydat, FR/1994 & NT & \\
\hline
\end{tabular}

* DK, Denmark; FI, Finland; FR, France; JP, Japan; NL, The Netherlands; NW, Norway.

$\uparrow$ A, Anatoxin-a; M, microcystin; N, neurotoxic; NT, no production of anatoxin-a or microcystin.

$\$$ References are indicated as: 1, Zevenboom et al. (1981); 2, Sivonen et al. (1989); 3, Sivonen et al. (1990); 4, Namikoshi et al. (1992a); 5, Namikoshi et al. (1992b); 6, Sivonen et al. (1992); 7, Rapala et al. (1993); 8, Rouhiainen et al. (1995); 9, Neilan et al. (1995); 10, Sivonen et al. (1995); 11, Lehtimäki et al. (1997); 12, Lyra et al. (1997); 13, Henriksen et al. (1997); 14, Neilan et al. (1997b); 15, Rapala et al. (1997); 16, Rudi et al. (1997); 17, Rudi et al. (1998); 18, Neilan et al. (1999); 19, Rudi \& Jakobsen (1999); 20, Lehtimäki et al. (2000); 21, Rouhiainen et al. (2000); 22, Lyra et al. (2001); 23, Gugger et al. (2002).

$\S$ Axenic culture.

\section{RESULTS}

Morphological and morphometric characteristics of
Anabaena and Aphanizomenon strains

The trichomes were coiled (Fig. 1a) to straight (Fig. 1b) in Anabaena strains, whereas they appeared straight and flexuous in Aphanizomenon strains (Fig. $1 \mathrm{c}, \mathrm{d})$. Some strains lost the diacritical features on which the original identification of the strains at the species level was made: Ap. flos-aquae lost the fasciclelike colonies (see Fig. 1d), Anabaena spiroides lost the regularity of the coiled trichomes and the akinetes 

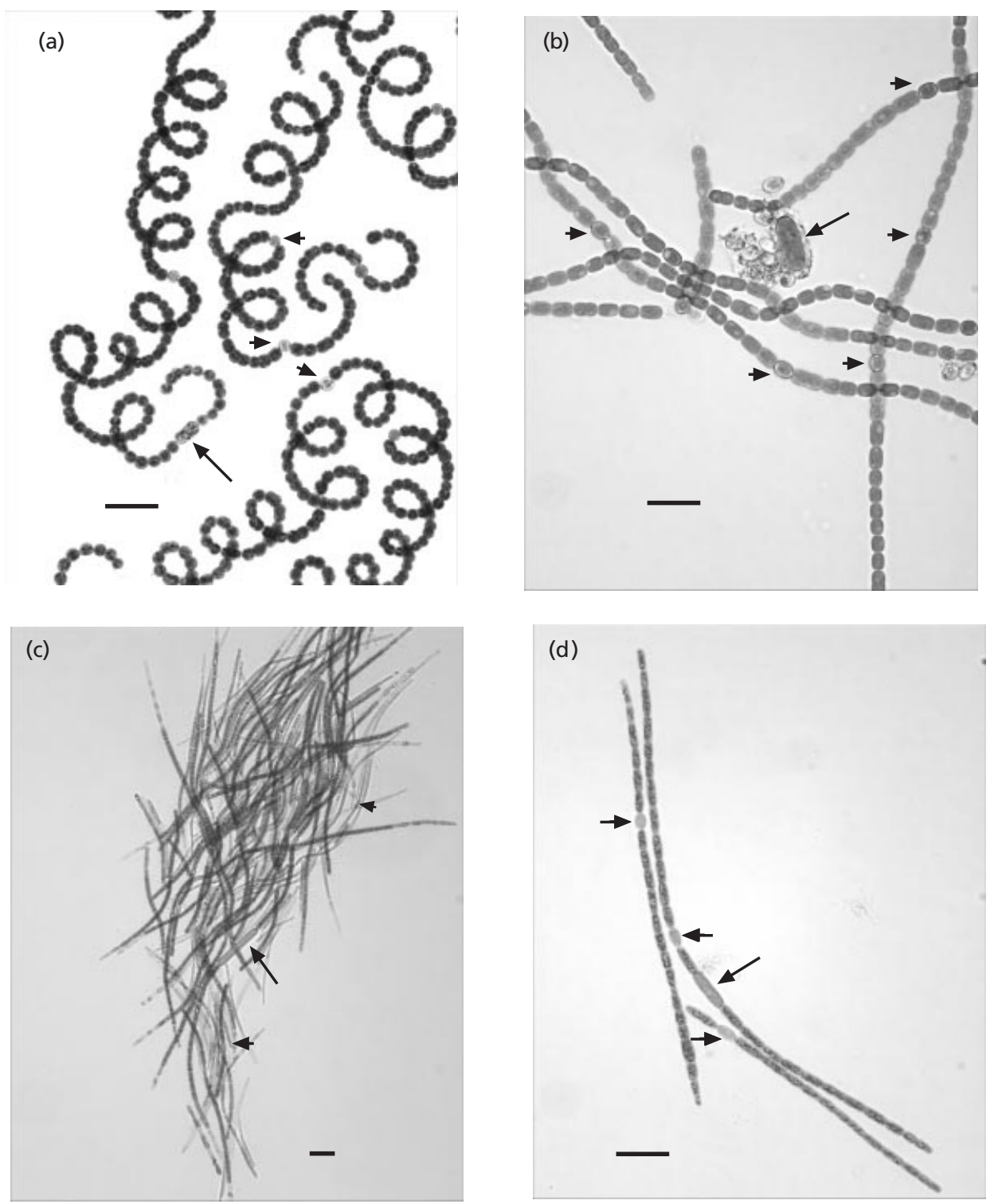

Fig. 1. Morphology of the trichomes in Anabaena and Aphanizomenon isolates. (a) Anabaena spiroides PMC9702. (b) Anabaena lemmermannii 202A2. (c) Aphanizomenon flos-aquae PMC9707. (d) Aphanizomenon flos-aquae TR183. Heterocysts are indicated by short arrows and akinetes are indicated by long arrows. Bars, $10 \mu \mathrm{m}$.

were not aggregated in the centre of the colonies of Anabaena lemmermannii. The size range of the cells did not correspond to the ones described for the species designation in Geitler's monograph. The vegetative cells of Anabaena strains were round or barrel-shaped (Fig. 1a, b), whereas they were cylindrical in Aphanizomenon (Fig. 1c, d). Most of the vegetative cells were 5-7 $\mu \mathrm{m}$ long in both genera (Fig. 2). The mean width of these cells was $<4 \mu \mathrm{m}$ for Aphanizomenon strains and $>4 \mu \mathrm{m}$ for Anabaena strains (Fig. 2). The heterocysts were round to oval in Anabaena and cylindrical in Aphanizomenon strains. The heterocysts were significantly $(P<0.05$; Mann-Whitney U test) wider in Anabaena than in Aphanizomenon strains (Fig. 2), they were 5-7 $\mu \mathrm{m}$ long and at the intercalary position in both genera. Anabaena sp. 277 and Ap. flos-aquae NIES 81 and PMC 9401 rarely produced heterocysts and lost their capacity to grow in medium without nitrogen. On the other hand, strains such as An. flosaquae 14, Anabaena sp. IC-1, An. lemmermannii 66A, An. cf. lemmermannii PH262, Anabaena solitaria 82 and Ap. flos-aquae PCC 7905 grew very well in Z8 medium without nitrogen but seldom showed differentiation of the cells to heterocysts and akinetes. The shapes of akinetes in the different Anabaena strains varied, whereas Aphanizomenon strains had only cylindrical akinetes. The akinetes were significantly $(P<0.05$; Mann-Whitney $\mathrm{U}$ test $)$ wider in Anabaena strains than in Aphanizomenon strains (Fig. 2). The terminal and vegetative cells were similar in Anabaena 
Vegetative cells $(n \boldsymbol{\square}=700, n \square=1300)$
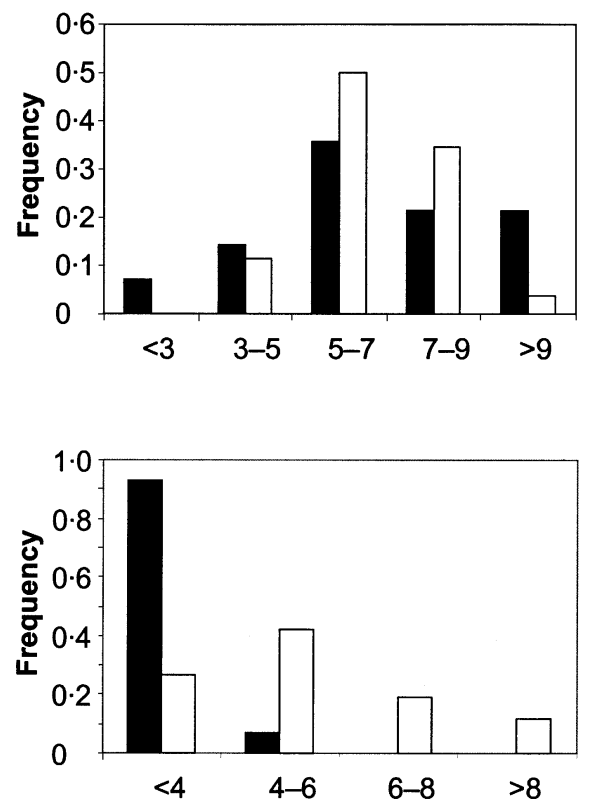

Heterocysts $(n \boldsymbol{\square}=195, n \square=337)$
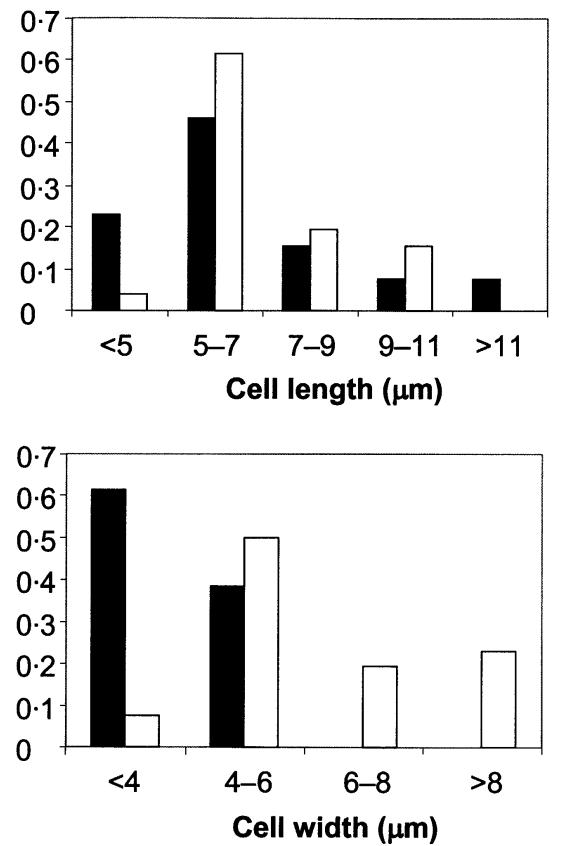

Akinetes $(n \square=100, n \square=206)$
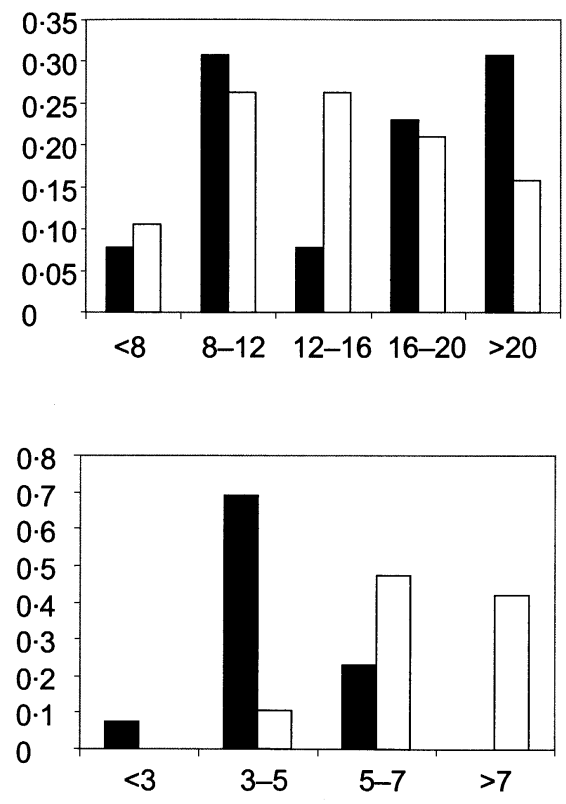

Fig. 2. Morphometric comparison of the lengths and widths of the different cells of Anabaena and Aphanizomenon trichomes. Frequencies of various size classes of vegetative cells, heterocysts and akinetes are indicated. Filled bars indicate Aphanizomenon strains and unfilled bars indicate Anabaena strains; $n$, number of cells measured.

strains, with the exception of the conical terminal cells of Anabaena cf. cylindrica PH133. The terminal cells of several Aphanizomenon strains were hyaline and often elongated. Gas vesicles were present in all strains except An. cf. cylindrica PH133.

\section{Genetic diversity of Anabaena and Aphanizomenon strains according to $16 \mathrm{~S}$ rRNA gene sequences}

Thirty almost-complete (1465 bp) 16S rDNAs sequenced in this study and 10 previously sequenced 16S rDNAs (Lyra et al., 2001) of Anabaena and Aphanizomenon strains were used to construct the phylogenetic trees. The neighbour-joining and parsimony $16 \mathrm{~S}$ rDNA trees were similar. Thus, only the parsimony tree for the phylogenetic relationship between Anabaena and Aphanizomenon strains is presented (Fig. 3).

The 16S rDNA tree revealed that strains of the genera Anabaena and Aphanizomenon were intermixed and thus not monophyletic (Fig. 3). The main clusters, 1, 2 and 3, were supported by high bootstrap values. Cluster 1 contained all anatoxin-a-producing Anabaena strains, 14, 37, 86, 123 and IC-1, non-toxic Anabaena strains PH57 and PH262 and non-toxic Ap. flos-aquae/Ap. gracile strains 202, PH219, PMC9706, TR183, PCC 7905, PMC9501 and NIES81. The Anabaena and Aphanizomenon strains of cluster 1 shared high similarity values of at least $99 \cdot 5 \%$. Cluster
2 was divided into two subclusters, $2 \mathrm{a}$ and $2 \mathrm{~b}$, containing six non-toxic Ap. flos-aquae/Ap. gracile strains (PMC9401, PMC9402, PMC9707, 326, PH218 and PH83) and five non-toxic Anabaena strains (PH215, PMC9301, PMC9403, PMC9701 and PMC9702), with similarity values $>99.7 \%$ and $98.9 \%$, respectively. The overall sequence similarity of cluster $2(>98 \%)$ supported by high bootstrap values (up to $83 \%$ in both phylogenetic reconstruction methods) revealed a tight grouping between the strains of the two genera. Cluster 3 contained all hepatotoxic Anabaena strains, 202A1, NC83/1, 202A2, 66A, PH256 and 90, and the non-toxic Anabaena sp. strain 299 and An. solitaria strain 82 . The $16 \mathrm{~S}$ rDNA sequences of Anabaena sp. strain 299 and An. lemmermannii strain PH256 were similar, while the sequences of $A n$. solitaria 82 and the other Anabaena strains of cluster 3 shared similarity values $<97.9 \%$. The four distinct branches contained non-toxic strains, An. cf. cylindrica PMC9705 and Ap. gracile PH271 (branch 4), the two non-toxic Anabaena compacta strains PH118 and PH189 (branch 5), the non-toxic Anabaena sp. strain 277 and Anabaena planctonica strain PH71 (branch 6) and neurotoxic Anabaena cf. cylindrica strain PH133 (branch 7). The two Anabaena strains 277 and PH71 and the other Anabaena strains in the tree shared similarity values $<97 \%$. An. cf. cylindrica $\mathrm{PH} 133$ and the other Anabaena strains shared sequence similarity $<94.6 \%$. 


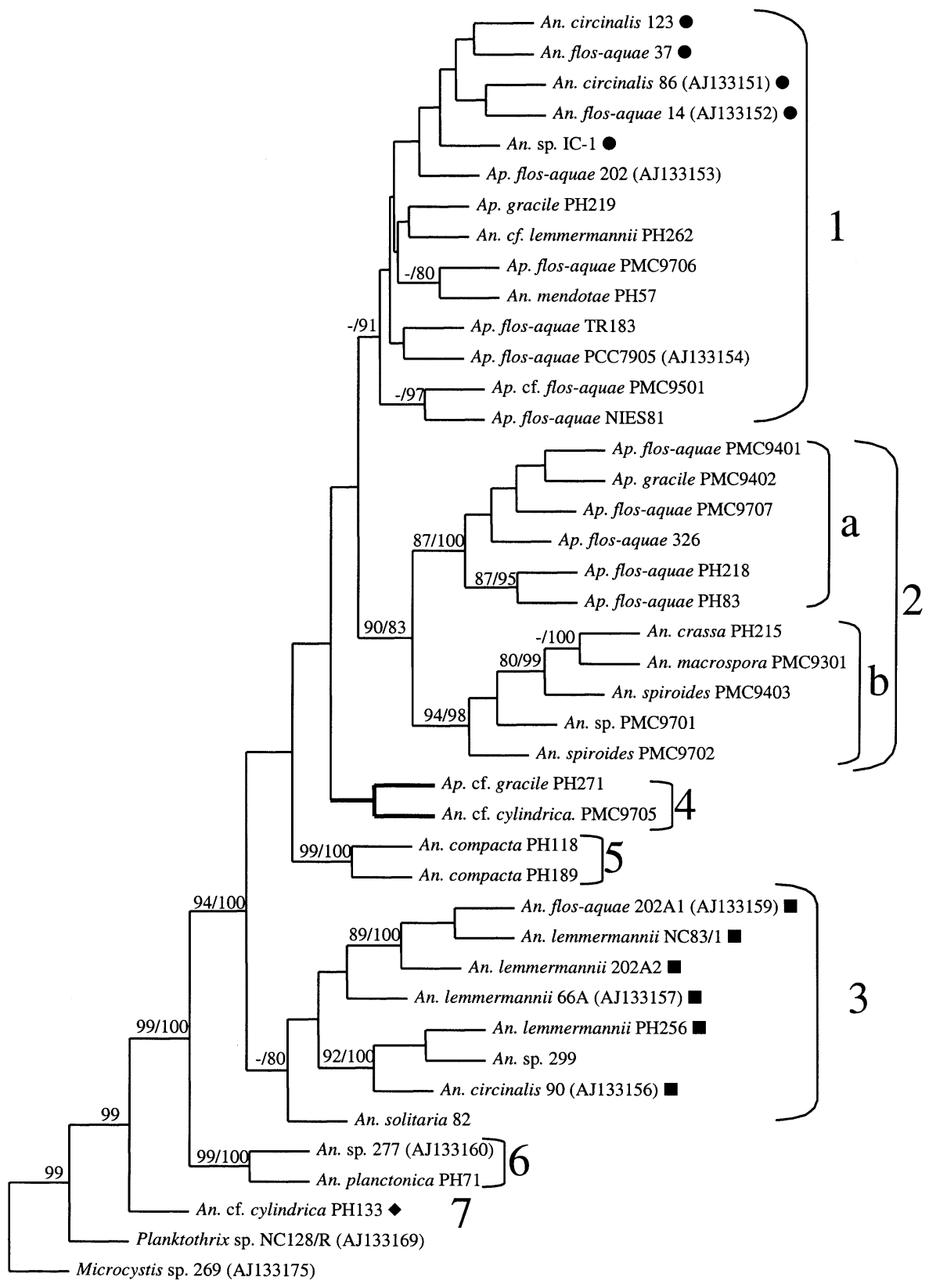

Fig. 3. Consensus parsimony tree based on $16 \mathrm{~S}$ rDNA sequences ( $1465 \mathrm{bp}$ ) of Anabaena and Aphanizomenon isolates. An., Anabaena; Ap., Aphanizomenon. Bootstrap values greater than $80 \%$ with parsimony/distance methods are indicated on the tree. Sequences from GenBank are indicated with accession numbers. The main clades are indicated by numbers and differences between the parsimony and distance trees are indicated by bold lines. Symbols: $\boldsymbol{\bullet}$, anatoxin-a producer; $\boldsymbol{\square}$, microcystin producer; $\diamond$, neurotoxic strain that does not produce anatoxin-a or -a(S).

\section{Genetic diversity of Anabaena and Aphanizomenon strains according to ITS1}

ITS1 length polymorphism. The lengths and numbers of ITS1 PCR products of Anabaena and Aphanizomenon strains are listed in Table 2. The amplified fragments contained the ITS1 region as well as 150 nucleotides of the 16S rRNA gene and 50 nucleotides of the $5^{\prime}$ end of the 23S rRNA gene. Multiple bands were observed in agarose gel electrophoresis (data not shown). Capillary electrophoresis in denaturing conditions revealed the presence of up to four products of different lengths. The shorter products, ranging from 450 to $500 \mathrm{bp}$, were designated ITS1-S and the longer products, ranging from 660 to $730 \mathrm{bp}$, were designated ITS1-L (Table 2). The overall lengths and numbers of PCR products of Anabaena and Aphanizomenon strains were similar.

ITS1 sequences. All ITS1 fragments of the strains $A n \mathrm{cf}$. 
Table 2. Lengths of the long and short ITS1 amplified products and the three types of ITS1-S sequence in Anabaena and Aphanizomenon strains

Lengths are expressed as numbers of nucleotides. The sequences represented by underlined numbers have been obtained by cloning.

\begin{tabular}{|c|c|c|c|c|c|}
\hline \multirow[t]{2}{*}{ Strain } & \multicolumn{2}{|c|}{ Length of ITS1 product } & \multicolumn{3}{|c|}{ ITS1-S type } \\
\hline & ITS1-L & ITS1-S & $\alpha$ & $\beta$ & $\gamma$ \\
\hline An. circinalis 86 & 700 & 475 & 272 & & \\
\hline An. circinalis $123^{*}$ & 700 & 475 & 272 & & \\
\hline An. circinalis $90^{*}$ & 709 & 476,478 & $\underline{274}$ & & \\
\hline An. compacta $\mathrm{PH} 118$ & 700,710 & 494 & $\overline{290}$ & & \\
\hline An. compacta $\mathrm{PH} 189$ & 701 & 493 & 290 & & \\
\hline An. crassa $\mathrm{PH} 215$ & 684,689 & 463,466 & $\underline{262}, \underline{265}$ & & \\
\hline An. cf. cylindrica $\mathrm{PH} 133$ & 705 & 498 & & & 295 \\
\hline An. cf. cylindrica PMC9705 & 701 & 474,501 & & 298 & \\
\hline An. flos-aquae 14 & 700 & 475 & 272 & & \\
\hline An. flos-aquae $37^{*}$ & 700 & 475 & 272 & & \\
\hline An. flos-aquae 202A1* & 703 & 503 & 298 & & \\
\hline An. lemmermannii $\mathrm{NC} 83 / 1 *$ & 704 & 503 & 299 & & \\
\hline An. lemmermannii 66A* & 710 & 505 & 300 & & \\
\hline An. lemmermannii 202A2/41* & 704 & 503 & 298 & & \\
\hline An. lemmermannii $\mathrm{PH} 256$ & 710 & 478,501 & 276 & & \\
\hline An. cf. lemmermannii PH262 & 701 & 473,500 & $\underline{272}$ & $\underline{298}$ & \\
\hline An. macrospora PMC9301 & 689 & 467 & 265 & & \\
\hline An. mendotae PH57 & 701 & 473,500 & & 298 & \\
\hline An. planctonica $\mathrm{PH} 71$ & 694 & 486 & 282 & & \\
\hline An. solitaria 82 & 741 & 496 & $\overline{293}$ & & \\
\hline An. spiroides PMC9403 & 687 & 466 & 265 & & \\
\hline An. spiroides PMC9702 & 694 & 482 & 280 & & \\
\hline Anabaena sp. PMC9701 & 704 & 482,486 & $\underline{279}$ & & \\
\hline Anabaena sp. $277^{*}$ & 662 & 448 & $\overline{249}$ & & \\
\hline Anabaena sp. 299 & 710 & 478 & 276 & & \\
\hline Anabaena sp. IC-1 & 700 & 475 & 272 & & \\
\hline Ap. flos-aquae NIES81* & 710,733 & 475,492 & 273 & & \\
\hline Ap. flos-aquae $202 *$ & 700,716 & 490,499 & & 288 & \\
\hline Ap. flos-aquae TR183 & 716 & 491 & & 288 & \\
\hline Ap. flos-aquae PMC9401 & 689 & 467,501 & 266 & & \\
\hline Ap. flos-aquae РМС9706 & 713 & 467 & 266 & & \\
\hline Ap. flos-aquae PMC9707 & 689 & 467,502 & 266 & & \\
\hline Ap. flos-aquae 326 & 689 & 468,473 & $\underline{267}, \underline{269}$ & & \\
\hline Ap. flos-aquae PCC 7905 & 714 & 491 & & 288 & \\
\hline Ap. flos-aquae PH83 & 682 & 471 & 269 & & \\
\hline Ap. flos-aquae $\mathrm{PH} 218$ & 682 & 471 & 269 & & \\
\hline Ap. cf. flos-aquae PMC9501 & 725 & $476,485,493$ & $\underline{273}$ & $\underline{282}, \underline{289}$ & \\
\hline Ap. gracile $\mathrm{PH} 219^{*}$ & 725 & 475,492 & 273 & & \\
\hline Ap. cf. gracile $\mathrm{PH} 271^{*}$ & 713 & 467 & 266 & & \\
\hline Ap. gracile PMC9402 & 689 & 467,502 & 266 & & \\
\hline
\end{tabular}

*Axenic culture.

lemmermannii PH262 and An. spiroides PMC9702 were sequenced to clarify the length difference between the short and long ITS1 PCR products. The ITS1-L sequences differed from ITS1-S by 201-228 bp, corresponding to the presence of tRNA ${ }^{\text {Ile }}$ and tRNA ${ }^{\mathrm{Ala}}$ genes and to variations in the length of the regions between the conserved domain D2 and the antiterminator box B. The ITS1-L products of strains $A n$. cf. lemmermannii $\mathrm{PH} 262$ and An. spiroides PMC9702 also differed in the same region. It was the most variable region in ITS1-S. In total, 45 ITS1-S PCR products (249-300 bp) were sequenced from Anabaena and 


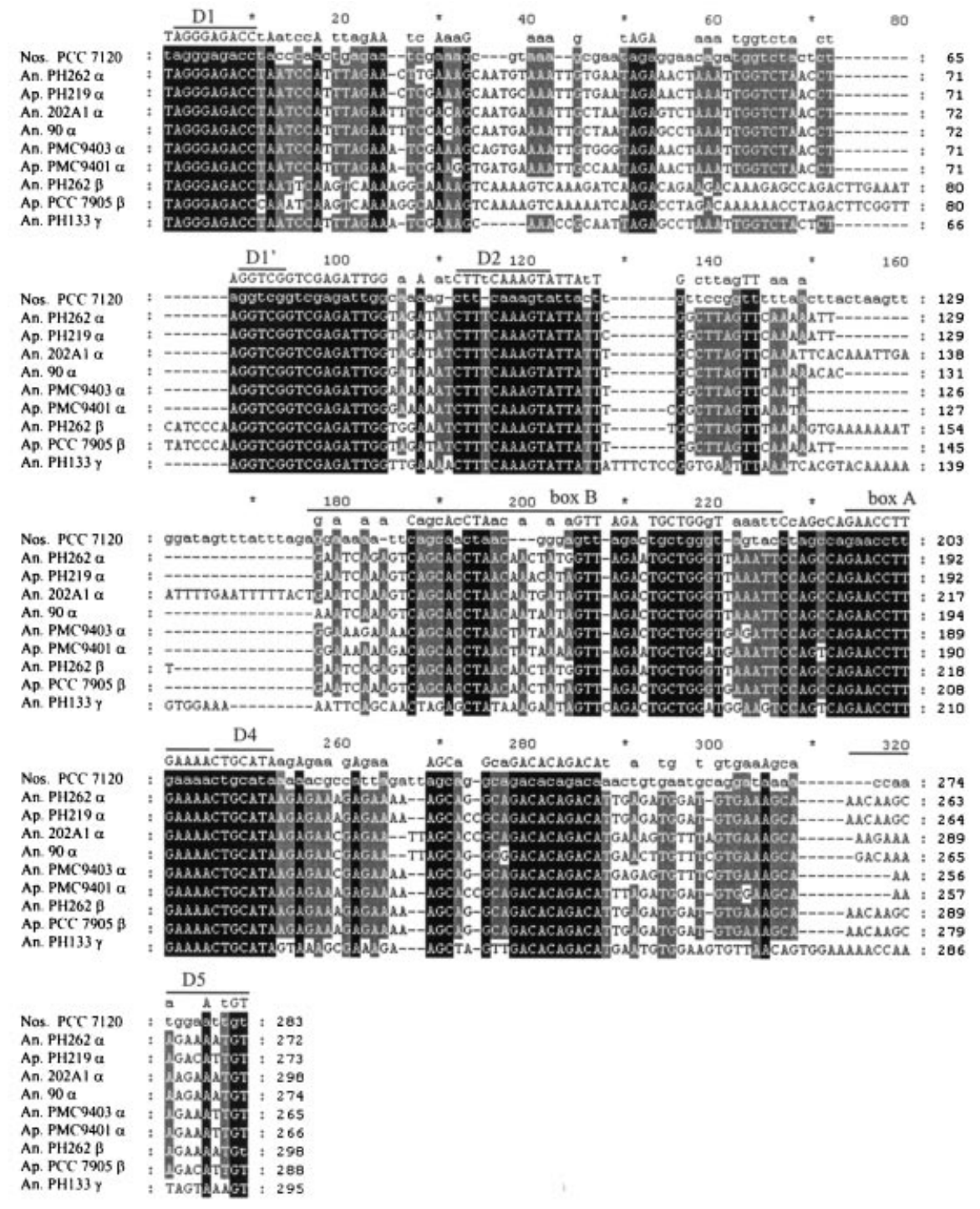

Fig. 4. Alignment of nucleotide sequences of the ITS1-S regions of types $\alpha, \beta$ and $\gamma$ from some representative Anabaena and Aphanizomenon strains. The conserved domains (D1, D1', D2, D4 and D5) and the antiterminator (boxes B and A) are located relative to the ITS1-S sequence from Nostoc PCC 7120 (AF180969). An., Anabaena; Ap., Aphanizomenon; Nos., Nostoc.

Aphanizomenon strains (Table 2). An alignment of some ITS1-S sequences is presented in Fig. 4. Three types of ITS1-S sequence were designated types $\alpha, \beta$ and $\gamma$ (Table 2 and Fig. 4). The ITS1-S sequence of type $\alpha$ was present in all strains except $A n$. cf. cylindrica PH133 and Ap. flos-aquae TR183 and PCC 7905 (Table 2). The $\beta$ type was found in eight of the 45 ITS1$\mathrm{S}$ sequenced (Table 2). It differed from the $\alpha$ type by the presence of 77 nucleotides and the absence of 61 nucleotides located between the two conserved domains D1 and D1' (Fig. 4). Both types of ITS1-S were observed in An. cf. lemmermannii PH262 and in Ap. cf. flos-aquae PMC9501 (Table 2, Figs 4 and 5). The $\gamma$ type was found in the neurotoxic $A n$. cf. cylindrica $\mathrm{PH} 133$ and the whole sequence differed from the $\alpha$ and $\beta$ types by several polymorphic sites (Fig. 4).
The ITS1-S tree. The neighbour-joining and parsimony trees based on ITS1-S sequences were similar. Thus, only the parsimony tree is presented (Fig. 5). The ITS1-S sequences formed three main clusters. Cluster 1 was divided into two subclusters, 1a and $1 \mathrm{~b}$ (Fig. 5). Subcluster 1a contained the type- $\alpha$ ITS1-S sequences of all anatoxin-a-producing Anabaena strains, 14, 37, 86, 123 and IC-1, the non-toxic An. cf. lemmermannii PH262 and the non-toxic Ap. flos-aquae/Ap. gracile strains PMC9501, PH219 and NIES81. Subcluster 1b contained all the type- $\beta$ ITS1-S sequences, belonging to Anabaena strains PH57 and PMC9705 and Aphanizomenon strains PCC 7905, TR 183 and 202 as well as An. cf. lemmermannii $\mathrm{PH} 262$ and Ap. cf. flos-aquae PMC9501. The ITS1-S sequence similarity values within subclusters $1 \mathrm{a}$ and $1 \mathrm{~b}$ were respectively 95 and 


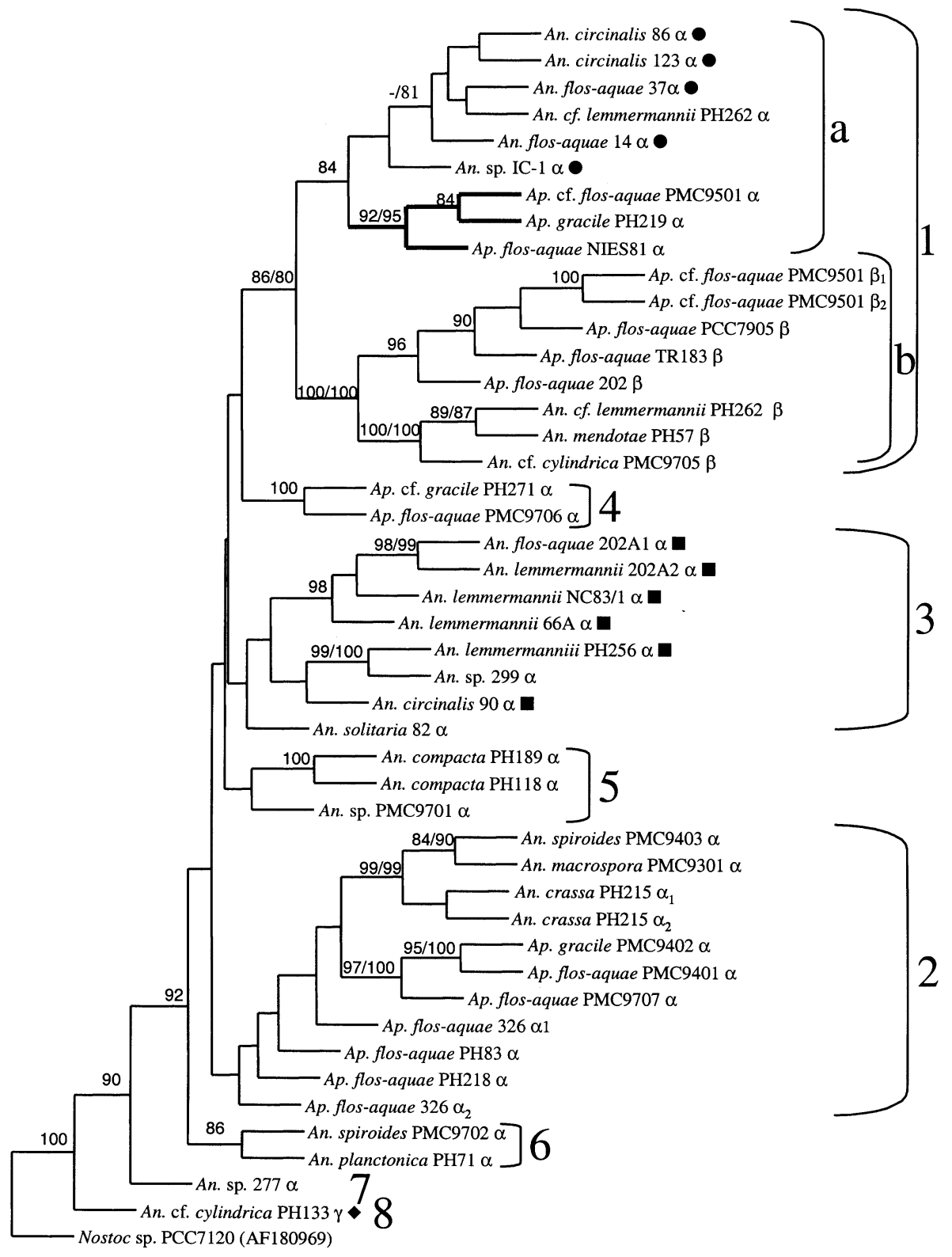

Fig. 5. Consensus parsimony tree based on ITS1-S sequences (249-300 bp) of Anabaena and Aphanizomenon isolates. See legend to Fig. 3 for further details.

$86 \%$. The ITS1-S sequence similarity values within each subcluster were higher than between the sequences of the two subclusters, showing that there is more diversity in the different ITS1-S copies of a single strain (e.g. $80 \%$ sequence similarity between the $\alpha$ and $\beta$-type sequences of An. cf. lemmermannii PH262) than between the homologous ITS1-S sequences of two strains. Cluster 2 contained the ITS1-S sequences of three non-toxic Anabaena strains (PMC9301, PMC9403 and PH215) and six non-toxic Aphanizomenon strains (PMC9401, PMC9402, PMC9707, 326, PH83 and PH218). The similarity of the ITS1-S sequences of the Anabaena and Aphanizomenon strains of cluster 2 was $>85 \%$. Cluster 3 grouped all hepatotoxic Anabaena strains (66A, NC83/1, 90, 202A1, 202A 2 and PH256) and two non-toxic Anabaena strains, 299 and 82 . The similarity values of the ITS1-S sequences in cluster 3 were $>82 \%$, with the exception of the more distantly related ITS1-S sequence of An. solitaria 82, which shared only $72 \%$ similarity with the other sequences in cluster 3 . Five separate branches contained the ITS1-S sequences of Ap. cf. gracile PH 271 and Ap. flos-aquae PMC9706 (branch 4), An. compacta strains PH118 and PH189 and Anabaena sp. PMC9701 (branch 5), An. spiroides PMC9702 and An. planctonica PH71 (branch 6) and Anabaena sp. 277 (branch 7). Branch 8 consisted of the type- $\gamma$ ITS1-S sequence of the neurotoxic $A n$. cf. 


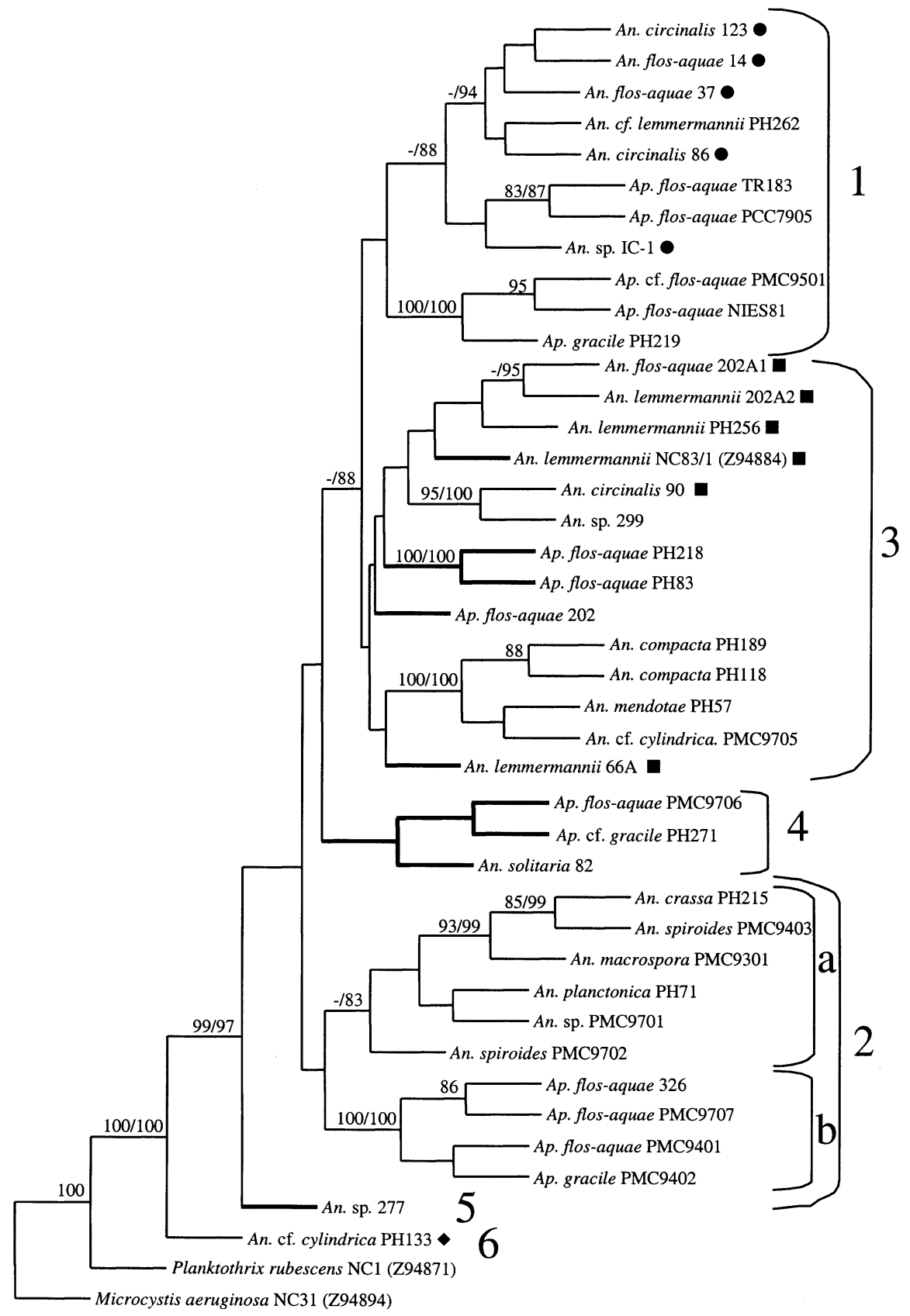

Fig. 6. Consensus parsimony tree based on $r b c L X$ sequences (650-793 bp) of Anabaena and Aphanizomenon isolates. See legend to Fig. 3 for further details.

cylindrica PH133 strain, which shared only $49 \%$ sequence similarity with the other Anabaena strains.

\section{The $r b c L X$ region}

The rbc $L X$ regions of 39 Anabaena and Aphanizomenon strains sequenced in this study and the regions of the An. lemmermannii NC83/1 sequenced by Rudi et al. (1998) were used to construct the trees. The region covered the end of the $r b c L$ gene (254 bp), an intergenic spacer (IGS1, $71 \mathrm{bp}$ ), the complete $r b c X$ gene (379 bp) and a second intergenic spacer (IGS2, $77 \mathrm{bp}$ ). The length of the rbcLX sequences in most strains was 783 bp. An. cf. cylindrica PH133 had the longest sequence (793 bp), due to the insertion of 15 nucleotides in IGS1. Anabaena strain PMC9701 had the shortest $r b c L X$ sequence (650 bp), due to the absence of $130 \mathrm{bp}$ in the $r b c X$ region. The parsimony and neighbour-joining trees of $r b c L X$ were congruent (Fig. 6). Sequences of Anabaena and Aphanizomenon strains were intermixed in the $r b c L X$ tree. Three main clusters, 1, 2 and 3, were observed (Fig. 6). Cluster 1 contained 
all anatoxin-a-producing Anabaena strains, 14, 37, 86, 123 and IC-1, non-toxic An. cf. lemmermannii PH262 and non-toxic Aphanizomenon strains TR183, PCC 7905, PMC9501, NIES81 and PH219. The Anabaena and Aphanizomenon rbcLX sequences of cluster 1 shared similarity of $>99.6 \%$. Cluster 2 was divided into two subclusters, $2 \mathrm{a}$ and $2 \mathrm{~b}$, respectively containing non-toxic Anabaena strains PH215, PMC9403, PMC9301, PH71, PMC9701 and PMC9702 and non-toxic Aphanizomenon strains 326, PMC9707, PMC9401 and PMC9402. The overall similarity value of the $r b c L X$ sequences within cluster 2 was $>97 \%$. Cluster 3 consisted of the hepatotoxic Anabaena strains 202A1, 202A2, PH256, NC83/1, 66A and 90 and non-toxic Anabaena strains 299, PH118, PH189, PH57 and PMC9705 and the non-toxic Aphanizomenon strains PH218, PH83 and 202. The sequence similarity in cluster 3 was $>97.6 \%$. Branch 4 consisted of Aphanizomenon strains PMC9706 and PH271 and An. solitaria 82. The separated branches contained Anabaena sp. 277 (branch 5) and neurotoxic An. cf. cylindrica PH133 (branch 6). The $r b c L X$ sequence of $A n$. cf. cylindrica $\mathrm{PH} 133$ shared only $87 \%$ similarity with the other Anabaena strains.

\section{Comparison of the clustering in the trees}

The strain composition of the three main clusters $(1,2$ and 3) was generally the same in the 16S rDNA, ITS1$\mathrm{S}$ and $r b c L X$ trees (Figs 3, 5 and 6). In cluster 1, the Anabaena strains producing anatoxin-a were always grouped with the same non-toxic Anabaena and Aphanizomenon strains (PH262, PH219, TR183, PCC7905, PMC9501 and NIES81). In cluster 2, the same non-toxic Anabaena strains (PH215, PMC9301, PMC9403 and PMC9701) and Aphanizomenon strains (326, PMC9401, PMC9402 and PMC9707) were clustered together in all the trees. Finally, cluster 3 always contained all the microcystin-producing Anabaena strains and the non-toxic Anabaena sp. 299. However, there were also differences between the trees and groupings. In the $16 \mathrm{~S}$ rDNA tree, Anabaena mendotae PH57 and Ap. flos-aquae PMC9706 were found together in cluster 1 (Fig. 3). In contrast, An. mendotae PH57 was associated with An. cf. lemmermannii PH262 in cluster 1 of the ITS1-S tree (Fig. 5) and with An. cf. cylindrica PMC9705 in cluster 3 of the $r b c L X$ trees (Fig. 6). The An. compacta strains PH189 and PH118 were situated in cluster 5 in the 16S rDNA and ITS-S trees but in cluster 3 in the $r b c L X$ tree. An. planctonica PH71 was grouped differently in all three trees.

\section{DISCUSSION}

Morphological observations of the Anabaena and Aphanizomenon cultures showed that some diacritical features used for species and genus determination were lost during isolation and cultivation, such as the ability to differentiate akinetes or heterocysts and to form the fascicle-like colonies typical of Ap.flos-aquae. Without these characters, species determination in the two genera is not feasible. In addition, the cell dimensions of the cultured strains did not correspond to the size range usually observed in the original species assignation. Similar changes have been observed previously for Anabaena (Stulp, 1982) and Nodularia strains (Lehtimäki et al., 2000; Laamanen et al., 2001). At the genus level, determination of the trichome structure (e.g. metameric or subsymmetric) was not possible for several strains. Nevertheless, general features such as bead-like cells in Anabaena were always distinguishable from the vegetative cells of Aphanizomenon, which had slightly constricted cell walls between two adjacent cells. Moreover, vegetative cells, heterocysts and akinetes were wider in Anabaena isolates than in Aphanizomenon isolates. Thus, Anabaena and Aphanizomenon strains were distinguishable on the basis of morphological criteria.

In contrast to the morphological classification, analyses of the 16S rDNA, ITS1-S and $r b c L X$ sequences of Anabaena and Aphanizomenon strains showed high similarity between Anabaena and Aphanizomenon strains and did not confirm the taxonomic validity of the two genera. The $16 \mathrm{~S}$ rDNA sequence similarity between certain Anabaena and Aphanizomenon strains was higher than the similarity observed between strains belonging to the genus Anabaena. The three analyses revealed that the genera Anabaena and Aphanizomenon are not monophyletic. Several previous studies based on 16S rDNA (Lyra et al., 1997, 2001; Rudi et al., 1998; Iteman et al., 1999) and DNA-dependent RNA polymerase (rpoC1) (Fergusson \& Saint, 2000) have shown that Anabaena and Aphanizomenon strains clustered together. It was also reported that genusspecific probes for $16 \mathrm{~S}$ rDNA designed for laboratory strains could not discriminate between Anabaena and Aphanizomenon in natural samples (Rudi et al., 2000).

The number, size or sequence of the ITS1 products, used for the classification of closely related cyanobacterial strains (Nelissen et al., 1994; Lu et al., 1997; Neilan et al., 1997b; Otsuka et al., 1999; Schedelman et al., 1999), did not allow the delineation of Anabaena and Aphanizomenon strains. However, the sizes and numbers of ITS products distinguished the two genera from other genera of the Nostocales such as Cylindrospermopsis, Raphidiopsis (M. Gugger, unpublished), Nodularia (Laamanen et al., 2001) and Nostoc (Iteman et al., 2000). The numbers of ITS1 products also indicate that Anabaena and Aphanizomenon strains have several different ribosomal operons. Three types of ITS1-S sequence were found in our isolates. The $\alpha$ and $\beta$ types of ITS1-S were found in the majority of our Anabaena and Aphanizomenon strains. The high similarity between these two types of sequence and their simultaneous presence within single strains of the two genera (e.g. Anabaena PH262 and Aphanizomenon PMC9501) revealed the recent divergence of the $\alpha$ and $\beta$ sequences. The ITS1-S sequence of type $\gamma$ found in An. cf. cylindrica $\mathrm{PH} 133$ was comparable to the $\alpha$ and $\beta$ types only in the conserved domains of the ITS1 
locus and was therefore highly divergent from the two other types of ITS1-S found in Anabaena and Aphanizomenon strains.

Stulp \& Stam (1985) found the genus Anabaena to be very homogeneous by morphological and DNA-DNA hybridization analyses. In contrast, this study and the previous studies of Lyra et al. $(1997,2001)$ have shown that the genus Anabaena is heterogeneous. Strain $A n$. cf. cylindrica PH133 did not contain gas vesicles, indicating that the strain is probably periphytic or benthic. Based on genotypic (16S rDNA, ITS1-S and $r b c L X$ ) and physiological (production of an unknown neurotoxin) criteria, we found An. cf. cylindrica PH133 to be considerably different from planktic Anabaena strains. Similarly, 16S rDNA studies on Anabaena sp. PCC 7108, originating from the intertidal zone in the USA (Rippka et al., 1979; Lyra et al., 2001), and Anabaena sp. NIES 19, originating either from Japan (see Beltran \& Neilan, 2000) or from pond water in the UK (synonymous to PCC 73105; see Neilan et al., 1995, 1999), and rpoCl of Anabaena bergii ANA283A, originating from Australia (Wilson et al., 2000; Fergusson \& Saint, 2000), showed that these strains are more related to other Nostocales isolates than to the cluster consisting of planktic Anabaena strains. The strains An. cf. cylindrica PH133, Anabaena sp. PCC 7108 (Lyra et al., 2001) and Anabaena sp. NIES19 (Beltran \& Neilan, 2000) shared $<95 \%$ 16S rDNA sequence similarity with the planktic Anabaena strains. This difference between the planktic Anabaena isolates and other Anabaena isolates cannot be explained by morphological misidentification but, instead, suggests that a re-evaluation of the genus Anabaena is needed. A recent study based on 16S rDNA sequences of seven Aphanizomenon strains demonstrated that the genus was monophyletic and in agreement with the morphological classification of the strains (Li et al., 2000). In this study, we compared Anabaena and Aphanizomenon strains and found that Aphanizomenon can not be regarded as monophyletic.

Phylogenies based on $r b c L X$ have been found to be incongruent with 16S rDNA phylogenies within the cyanobacteria and purple bacteria (Watson \& Tabita, 1997; Rudi et al., 1998). Study of three different loci of the same strains showed overall similarity of the $\operatorname{rbc} L X, 16 \mathrm{~S}$ rDNA and ITS-S trees, with three main clusters and two branches containing Anabaena sp. 277 and An. cf. cylindrica PH133 always near the root of the tree. Comparison of the 16S rDNA and $r b c L X$ phylogenies revealed that 11 of 14 strains contained in cluster 1,9 of 11 strains of cluster 2 and 7 of 8 strains of cluster 3 in the $16 \mathrm{~S}$ rDNA tree were grouped similarly in the $r b c L X$ tree. However, a few differences were also found, such as the number of strains contained in cluster 3, but this cluster in the $r b c L X$ tree is not supported by its bootstrap percentage. Our strains could be placed in the cluster 'Nostoc lineage I' described by Rudi et al. (1998). Compared with the latter study, less variability was observed in the $r b c L X$ nucleotide sequences of Anabaena and Aphanizomenon isolates (as shown by the high sequence similarities in each cluster). This could be related to the larger number of strains in this study. According to the results of Rudi et al. (1998), this observation suggested that there might be lateral gene transfer between Anabaena and Aphanizomenon strains.

Anabaena strains that produce different types of toxin clustered separately from each other in the $16 \mathrm{~S} \mathrm{rDNA}$, ITS1-S and $r b c L X$ trees. The first cluster contained anatoxin-a-producing Anabaena strains and non-toxic strains from both genera. The second cluster contained non-toxic Anabaena strains and non-toxic Aphanizomenon strains and the third cluster contained microcystin-producing and non-toxic Anabaena strains. Despite their diverse geographical origins, Anabaena strains that produce similar toxic compounds were clustered together in the 16S rDNA, ITS1-S and $r b c L X$ trees, highlighting that these strains have evolved from the same ancestor. In the order Nostocales, corresponding results have been found within the genera Anabaena (Lyra et al., 1997, 2001; Beltran \& Neilan, 2000) and Nodularia (Lehtimäki et al., 2000; Laamanen et al., 2001). Anabaena strains producing anatoxin-a, anatoxin-a(S), microcystins, saxitoxin and an unknown neurotoxin grouped separately based on 16S rDNA sequences (Lyra et al., 1997, 2001; Beltran \& Neilan, 2000; this study). Each cluster of strains that produce a specific toxin also contained non-toxic strains. These clusters are noticeable within the Anabaena strains that produce microcystins or anatoxin-a (Lyra et al., 2001; this study) and for the one that produces saxitoxin (Beltran \& Neilan, 2001), but also amongst clusters of other genera that produce the same type of hepatotoxin, microcystins, such as Microcystis or Planktothrix (Neilan et al., 1997a; Otsuka et al., 1999; Lyra et al., 2001). Whether these non-toxic strains have toxin genes at all or whether they contain inactivated toxin genes remains to be studied.

The 16S rDNA sequence similarity of Anabaena and Aphanizomenon strains was higher than $97.5 \%$, which indicates that the strains of the two genera belong to the same species (Stackebrandt \& Goebel, 1994). Previously, the study of Palinska et al. (1996) revealed 16S rDNA similarity of morphologically different isolates from the genera Merismopedia and Synechocystis. Polyphasic studies on morphology, 16S rDNA sequences, polymorphic loci or DNA hybridization have revealed genetic similarity of several Microcystis species (Otsuka et al., 1998, 1999, 2001; Kondo et al., 2000). In addition, Planktothrix strains with different pigments were genotypically similar (Humbert \& Leberre, 2001; Lyra et al., 2001). Recent studies of Nübel et al. (2000) and Rippka et al. (2000) have also emphasized the need for multidisciplinary studies to understand the diversity of the cyanobacteria. On the basis of the congruent results obtained by genetic (Lyra et al., 2001; this study), whole-cell protein (Lyra et al., 1997) and fatty acid (Li et al., 1998; Gugger et al., 2002) analyses, the taxonomic validity of the genera 
Aphanizomenon and Anabaena seems to be questionable, even though morphological and morphometric characterizations support the distinction made between these two genera. The differences between molecular and morphological results may reflect the existence of species variants in populations or ecotypes adapted to different environmental conditions.

\section{ACKNOWLEDGEMENTS}

We thank Matti Wahlsten for his technical assistance, Aneta Dresler for expertise at the ABI PRISM 310 Genetic Analyzer and Maria Laamanen for her critical reading of the manuscript. We are grateful to Professor W. W. Carmichael for kindly providing anatoxin-a Anabaena IC-1 and to J.-C. Romagou for French Anabaena and Aphanizomenon strains. This study was supported by grants from Helsinki University and the Academy of Finland to K. S. and from the Centre for International Mobility (CIMO) to M. G.

\section{REFERENCES}

Banker, R., Carmeli, S., Hadas, O., Teltsch, B., Porat, R. \& Sukenik, A. (1997). Identification of cylindropsermopsin in Aphanizomenon ovalisporum (Cyanophyceae) isolated from Lake Kinneret, Israel. J Phycol 33, 613-616.

Banker, R., Teltsch, B., Sukenik, A. \& Carmeli, S. (2000). 7Epicylindrospermopsin, a toxic minor metabolite of the cyanobacterium Aphanizomenon ovalisporum from lake Kinneret, Israel. J Nat Prod 63, 387-389.

Barker, G. L. A., Konopka, A., Handley, B. A. \& Hayes, P. K. (2000). Genetic variation in Aphanizomenon (Cyanobacteria) colonies from the Baltic Sea and North America. J Phycol 36, 947-950.

Beltran, E. C. \& Neilan, B. A. (2000). Geographical segregation of the neurotoxin-producing cyanobacterium Anabaena circinalis. Appl Environ Microbiol 66, 4468-4474.

De Nobel, W. T., Huisman, J., Snoep, J. L. \& Mur, L. R. (1997). Competition for phosphorus between the nitrogen-fixing cyanobacteria Anabaena and Aphanizomenon. FEMS Microbiol Ecol 24, 259-267.

De Nobel, W. T., Matthijs, H. C. P., Von Elert, E. \& Mur, L. R. (1998). Comparison of the light-limited growth of the nitrogen-fixing cyanobacteria Anabaena and Aphanizomenon. New Phytol 138, 579-587.

Felsenstein, J. (1993). PHYLIP (Phylogeny Inference Package), version 3.5c. Department of Genetics, University of Washington, Seattle, USA. Fergusson, K. M. \& Saint, C. P. (2000). Molecular phylogeny of Anabaena circinalis and its identification in environmental samples by PCR. Appl Environ Microbiol 66, 4145-4148.

Geitler, L. (1932). Cyanophyceae. In Rabenhorst's Kryptogamenflora, vol. 14, pp. 1-1196. Leipzig: Akademische Verlagsgesellschaft.

Gugger, M., Lyra, C., Suominen, I., Tsitko, I., Humbert, J.-F., Salkinoja-Salonen, M. S. \& Sivonen, K. (2002). Cellular fatty acids as chemotaxonomic markers of the genera Anabaena, Aphanizomenon, Microcystis, Nostoc and Planktothrix (cyanobacteria). Int J Syst Evol Microbiol 52, 1007-1015.

Henriksen, P. (1996). Microcystin profiles and contents in Danish populations of cyanobacteria/blue-green algae as determined by HPLC. Phycologia 35, 102-110.

Henriksen, P., Carmichael, W. W., An, J. \& Moestrup, Ø. (1997). Detection of an anatoxin-a(S)-like anticholinesterase in natural blooms and cultures of cyanobacteria/blue-green algae from Danish lakes and in the stomach contents of poisoned birds. Toxicon 35, 901-913.

Humbert, J.-F. \& Leberre, B. (2001). Genetic diversity in two species of freshwater cyanobacteria, Planktothrix (Oscillatoria) rubescens and P. agardhii. Arch Hydrobiol 150, 197-206.

Iteman, I., Rippka, R., Tandeau de Marsac, N. \& Herdman, M. (1999). Use of molecular tools for the study of genetic relationships of heterocystous cyanobacteria. In Marine Cyanobacteria, vol. 19, pp. 13-20. Edited by L. Charpy \& A. W. D. Larkum. Monaco: Bulletin de l'Institut Océanographique.

Iteman, I., Rippka, R., Tandeau de Marsac, N. \& Herdman, M. (2000). Comparison of conserved structural and regulatory domains within divergent $16 \mathrm{~S}$ rRNA-23S rRNA spacer sequences of cyanobacteria. Microbiology 146, 1275-1286.

Komárek, J. \& Anagnostidis, K. (1989). Modern approach to the classification system of Cyanophytes. 4. Nostocales. Arch Hydrobiol Suppl 82, 247-345.

Komárek, J. \& Kováčik, L. (1989). Trichome structure of four Aphanizomenon taxa (Cyanophyceae) from Czechoslovakia, with notes on the taxonomy and delimitation of the genus. Plant Syst Evol 164, 47-64.

Kondo, R., Yoshida, T., Yuki, Y. \& Hiroishi, S. (2000). DNA-DNA reassociation among a bloom-forming cyanobacterial genus, Microcystis. Int J Syst Evol Microbiol 50, 767-770.

Kotai, J. (1972). Instructions for Preparation of Modified Nutrient Solution Z8 for Algae. Publication B-11/69. Blindern, Oslo: Norwegian Institute for Water Research.

Laamanen, M. J., Gugger, M. F., Lehtimäki, J. M., Haukka, K. \& Sivonen, K. (2001). Diversity of toxic and nontoxic Nodularia isolates (Cyanobacteria) and filaments from the Baltic Sea. Appl Environ Microbiol 67, 4638-4647.

Lane, D. J. (1991). 16S/23S rDNA sequencing. In Nucleic Acid Techniques in Bacterial Systematics, pp. 115-174. Edited by E. Stackebrandt \& M. Goodfellow. Chichester: Wiley.

Lehtimäki, J., Moisander, P., Sivonen, K. \& Kononen, K. (1997). Growth, nitrogen fixation, and nodularin production by two Baltic Sea cyanobacteria. Appl Environ Microbiol 63, 1647-1656.

Lehtimäki, J., Lyra, C., Suomalainen, S., Sundman, P., Rouhiainen, L., Paulin, L., Salkinoja-Salonen, M. \& Sivonen, K. (2000). Characterization of Nodularia strains, cyanobacteria from brackish waters, by genotypic and phenotypic methods. Int J Syst Evol Microbiol 50, 1043-1053.

Li, R., Yokota, A., Sugiyama, J., Watanabe, M., Hiroki, M. \& Watanabe, M. M. (1998). Chemotaxonomy of planktonic cyanobacteria based on non-polar and 3-hydroxy fatty acid composition. Phycol Res 46, 21-28.

Li, R., Carmichael, W. W., Liu, Y. \& Watanabe, M. M. (2000). Taxonomic re-evaluation of Aphanizomenon flos-aquae NH-5 based on morphology and 16S rRNA gene sequences. Hydrobiologia 438, 99-105. Lu, W., Evans, E. H., McColl, S. M. \& Saunders, V. A. (1997). Identification of cyanobacteria by polymorphisms of PCR-amplified rDNA spacer region. FEMS Microbiol Lett 153, 141-149.

Lyra, C., Hantula, J., Vainio, E., Rapala, J., Rouhiainen, L. \& Sivonen, K. (1997). Characterization of cyanobacteria by SDS-PAGE of whole-cell proteins and PCR/RFLP of the 16S rRNA gene. Arch Microbiol 168, 176-184.

Lyra, C., Suomalainen, S., Gugger, M., Vezie, C., Sundman, P., Paulin, L. \& Sivonen, K. (2001). Molecular characterization of planktic cyanobacteria of Anabaena, Aphanizomenon, Microcystis and Planktothrix genera. Int J Syst Evol Microbiol 51, 513-526.

Namikoshi, M., Sivonen, K., Evans, W. R., Carmichael, W. W., Rouhiainen, L., Luukkainen, R. \& Rinehart, K. L. (1992a). Structures of three new homotyrosine-containing microcystins and a new homophenylalanine variant from Anabaena sp. strain 66. Chem Res Toxicol 5, 661-666.

Namikoshi, M., Sivonen, K., Evans, W. R., Carmichael, W. W., Sun, F., Rouhiainen, L., Luukkainen, R. \& Rinehart, K. L. (1992b). Two new L-serine variants of microcystins-LR and -RR from Anabaena sp. strains 202 A1 and 202 A2. Toxicon 30, 1457-1464.

Neilan, B. A., Jacobs, D. \& Goodman, A. E. (1995). Genetic diversity and phylogeny of toxic cyanobacteria determined by DNA polymorphisms within phycocyanin locus. Appl Environ Microbiol 61, 38753883 .

Neilan, B. A., Jacobs, D., Del Dot, T., Blackall, L. L., Hawkins, P. R., Cox, P. T. \& Goodman, A. E. (1997a). rRNA sequences and evol- 
utionary relationships among toxic and nontoxic cyanobacteria of the genus Microcystis. Int J Syst Bacteriol 47, 693-697.

Neilan, B. A., Stuart, J. L., Goodman, A. E., Cox, P. T. \& Hawkins, P. R. (1997b). Specific amplification and restriction polymorphisms of the cyanobacterial rRNA operon spacer region. Syst Appl Microbiol 20, 612-621.

Neilan, B. A., Dittmann, E., Rouhiainen, L., Bass, R. A., Schaub, V., Sivonen, K. \& Börner, T. (1999). Non ribosomal peptide synthesis and toxigenicity of cyanobacteria. J Bacteriol 181, 4089-4097.

Nelissen, B., Wilmotte, A., Neefs, J.-M. \& De Watcher, R. (1994). Phylogenetic relationships among filamentous helical cyanobacteria investigated on the basis of 16S rRNA gene sequence analysis. Syst Appl Microbiol 17, 206-210.

Nicholas, K. B. \& Nicholas, H. B., Jr (1997). GeneDoc: a tool for editing and annotating multiple sequence alignments. Distributed by the authors (http://www.psc.edu/biomed/genedoc).

Nübel, U., Garcia-Pichel, F. \& Muyzer, G. (2000). The halotolerance and phylogeny of cyanobacteria with tightly coiled trichomes (Spirulina Turpin) and the description of Halospirulina gen. nov., sp. nov. Int J Syst Evol Microbiol 50, 1265-1277.

Otsuka, S., Suda, S., Li, R., Watanabe, M., Oyaizu, H., Matsumoto, S. \& Watanabe, M. M. (1998). 16S rDNA sequences and phylogenetic analyses of Microcystis strains with and without phycoerythrin. FEMS Microbiol Lett 164, 119-124.

Otsuka, S., Suda, S., Li, R., Watanabe, M., Oyaizu, H., Matsumoto, S. \& Watanabe, M. M. (1999). Phylogenetic relationships between toxic and non-toxic strains of the genus Microcystis based on $16 \mathrm{~S}$ to $23 \mathrm{~S}$ internal transcribed spacer sequence. FEMS Microbiol Lett 172, 15-21.

Otsuka, S., Suda, S., Shibata, S., Oyaizu, H., Matsumoto, S. \& Watanabe, M. M. (2001). A proposal for the unification of five species of the cyanobacterial genus Microcystis Kützing ex Lemmermann 1907 under the Rules of the Bacteriological Code. Int J Syst Evol Microbiol 51, 873-879.

Page, R. D. M. (1996). TreeView: an application to display phylogenetic trees on personal computers. Comput Appl Biosci 12, 357-358. Palinska, K. A., Liesack, W., Rhiel, E. \& Krumbein, W. E. (1996). Phenotype variability of identical genotypes: the need for a combined approach in cyanobacterial taxonomy demonstrated on Merismopedialike isolates. Arch Microbiol 166, 224-233.

Rapala, J., Sivonen, K., Luukkainen, R. \& Niemelä, S. I. (1993). Anatoxin-a concentration in Anabaena and Aphanizomenon under different environmental conditions and comparison of growth by toxic and non-toxic Anabaena strains - a laboratory study. J Appl Phycol 5, 581-591.

Rapala, J., Sivonen, K., Lyra, C. \& Niemelä, S. I. (1997). Variation of microcystins, cyanobacterial hepatotoxins, in Anabaena spp. as a function of growth stimuli. Appl Environ Microbiol 63, 2206-2212.

Rippka, R., Deruelles, J., Waterbury, J. B., Herdman, M. \& Stanier, R. Y. (1979). Generic assignments, strain histories and properties of pure cultures of cyanobacteria. J Gen Microbiol 111, 1-61.

Rippka, R., Coursin, T., Hess, W. \& 7 other authors (2000). Prochlorococcus marinus Chisholm et al. 1992 subsp. pastoris subsp. nov. strain PCC 9511, the first axenic chlorophyll $a_{2} / b_{2}$-containing cyanobacterium (Oxyphotobacteria). Int J Syst Evol Microbiol 50, 1833-1847.

Rippka, R., Castenholz, R. W. \& Herdman, M. (2001). Subsection IV (formerly Nostocales Castenholz 1989b sensu Rippka, Deruelles, Herdman and Stanier 1979). In Bergey's Manual of Systematic Bacteriology, 2nd edn, vol. 1, pp. 562-566. Edited by D. R. Boone \& R. W. Castenholz. New York: Springer-Verlag.

Rouhiainen, L., Sivonen, K., Buikema, W. J. \& Haselkorn, R. (1995). Characterization of toxin-producing cyanobacteria by using an oligonucleotide probe containing a tandemly repeated heptamer. $J$ Bacteriol 177, 6021-6026.
Rouhiainen, L., Paulin, L., Suomalainen, S., Hyytiäinen, H., Buikema, W., Haselkorn, R. \& Sivonen, K. (2000). Genes encoding synthetases of cyclic depsipeptides, anabaenopeptilides, in Anabaena strain 90. Mol Microbiol 37, 156-167.

Rudi, K. \& Jakobsen, K. S. (1999). Complex evolutionary patterns of tRNA $^{\text {Leu }}$ (UAA) group I introns in cyanobacterial radiation. $J$ Bacteriol 181, 3445-3451.

Rudi, K., Skulberg, O. M., Larsen, F. \& Jakobsen, K. S. (1997). Strain characterization and classification of oxyphotobacteria in clone cultures on the basis of $16 \mathrm{~S}$ rRNA sequences from the variable regions V6, V7, and V8. Appl Environ Microbiol 63, 2593-2599.

Rudi, K., Skulberg, O. M. \& Jakobsen, K. S. (1998). Evolution of cyanobacteria by exchange of genetic material among phyletically related strains. J Bacteriol 180, 3453-3461.

Rudi, K., Skulberg, O. M., Skulberg, R. \& Jakobsen, K. S. (2000). Application of sequence-specific labelled 16S rRNA gene oligonucleotide probes for genetic profiling of cyanobacterial abundance and diversity by array hybridization. Appl Environ Microbiol 66, 4004-4011.

Scheldeman, P., Baurain, D., Bouhy, R., Scott, M., Mühling, M., Whitton, B. A., Belay, A. \& Wilmotte, A. (1999). Arthrospira ('Spirulina') strains from four continents are resolved into only two clusters, based on amplified rDNA restriction analysis of the internal transcribed spacer. FEMS Microbiol Lett 172, 213-222.

Sivonen, K. \& Jones, G. (1999). Cyanobacterial toxins. In Toxic Cyanobacteria in Water. A Guide to their Public Health Consequences, Monitoring and Management, pp. 41-111. Edited by I. Chorus \& J. Bartram. London: E. \& F. N. Spon.

Sivonen, K., Himberg, K., Luukkainen, R., Niemelä, S. I., Poon, G. K. \& Codd, G. A. (1989). Preliminary characterization of neurotoxic cyanobacteria blooms and strains from Finland. Toxic Assess 4, 339-352.

Sivonen, K., Niemelä, S. I., Niemi, R. M., Lepistö, L., Luoma, T. H. \& Räsänen, L. A. (1990). Toxic cyanobacteria (blue-green algae) in Finnish fresh and coastal waters. Hydrobiologia 190, 270-275.

Sivonen, K., Namikoshi, M., Evans, W. R., Carmichael, W. W., Sun, F., Rouhiainen, L., Luukkainen, R. \& Rinehart, K. L. (1992). Isolation and characterization of a variety of microcystins from seven strains of the cyanobacterial genus Anabaena. Appl Environ Microbiol 58, 24952500 .

Sivonen, K., Namikoshi, M., Luukkainen, R., Färdig, M., Rouhiainen, L., Evans, W. R., Carmichael, W. W., Rinehart, K. L. \& Niemelä, S. (1995). Variation of cyanobacterial hepatotoxins in Finland. In The Contaminants in the Nordic Ecosystems: Dynamics, Processes \& Fate, pp. 163-169. Ecovision Word Monograph Series. Edited by M. Munawar \& M. Luotola. Amsterdam: SPB Academic Publishing.

Stackebrandt, E. \& Goebel, B. M. (1994). Taxonomic note: a place for DNA-DNA reassociation and 16S rRNA sequence analysis in the present species definition in bacteriology. Int J Syst Bacteriol 44, 846-849.

Stulp, B. K. (1982). Morphological variability of Anabaena strains (Cyanophyceae) under different culture conditions. Arch Hydrobiol Suppl 63, 165-176.

Stulp, B. K. \& Stam, W. T. (1985). Taxonomy of the genus Anabaena (Cyanophyceae) based on morphological and genotypic criteria. Arch Hydrobiol Suppl 71, 257-268.

Watson, M. F. \& Tabita, R. (1997). Microbial ribulose 1,5-bisphosphate carboxylase/oxygenase: a molecule for phylogenetic and enzymological investigation. FEMS Microbiol Lett 146, 13-22.

Wilson, K. M., Schembri, M. A., Baker, P. D. \& Saint, C. (2000). Molecular characterization of the toxic cyanobacterium Cylindrospermopsis raciborskii and design of species-specific PCR. Appl Environ Microbiol 66, 332-338.

Zevenboom, W., Van Der Does, J., Bruning, K. \& Mur, L. R. (1981). A non-heterocystous mutant of Aphanizomenon flos-aquae, selected by competition in light-limited continuous culture. FEMS Microbiol Lett 10, 11-16. 